\title{
L-Lake Macroinvertebrate Community (U)
}

Winona L. Specht

Westinghouse Savannah River Company

Savannah River Site

Aiken, SC 29808

June 1996

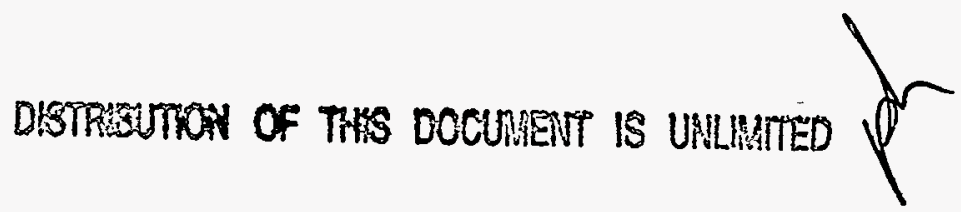

UNCLASSIFIED

DOES NOT CONTAIN

UNCLASSIFIED CONTROLLED

NUCLEAR INFORMATION

AOC \&

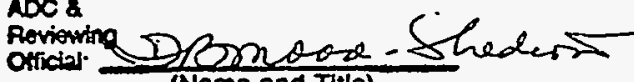

Dato: $\quad 71 /$ (N) $/ 96$

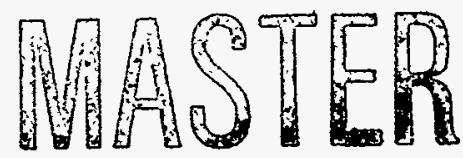

The information contained in this report was developed during the course of work under Contract No. DE-AC09-89SR18035 with the U.S. Department of Energy. 


\section{Disclaimer}

This report was prepared as an account of work sponsored by an agency of the United States Government. Neither the United States Government nor any agency thereof, nor-any of their employees, makes any warranty, expressed or implied, or assumes any legal liability or responsibility for the accuracy, completèness, or usefulnèss of any information, apparatus, product, or process disclosed, or represents that its use would not infringe privately owned rights. Reference herein to any specific commercial product, process, or service by trade name, trademark, manufacturer, or otherwise does not necessarily constitute or imply its endorsement, recommendation, or favoring by the United States Government or any agency thereof. The views and opinions of authors expressed herein do not necessarily state or reflect those of the United States Government or any agency thereof. 


\section{DISCLATMER}

This report was prepared as an account of.work sponsored by an agency of the United States Government. Neither the United.States Government nor any agency thereof, nor any of their employees, makes any warranty, express or implied, or assumes any legal liability or responsibility for the accuracy, completeness, or usefulness of any information, apparatus, product, or process disclosed, or represents that its use would not infringe privately owned rights. Reference herein to any specific commercial product, process, or service by trade name, trademark, manufacturer, or otherwise does not necessarily constitute or imply its endorsement, recommendation, or favoring by the United States Government or any agency thereof. The views and opinions of authors expressed herein do not necessarily state or reflect those of the United States Government or any agency thereof.

This report has been reproduced directly from the best available copy.

Available to DOE and DOE contractors from the Office of Scientific and Technical Information, P.O. Box 62, Oak Ridge, TN 37831; prices available from (615) 576-8401.

Available to the public from the National Technical Information Service, U.S. Department of Commerce, 5285 Port Royal Road, Springfield, VA 22161. 


\section{DISCLAIMER}

Portions of this document may be illegible in electronic image products. Images are produced from the best available original document. 


\section{Table of Contents}

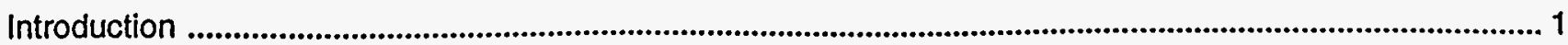

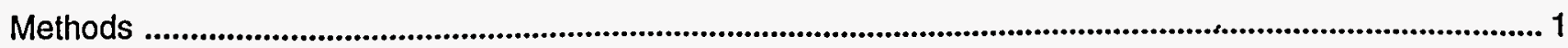

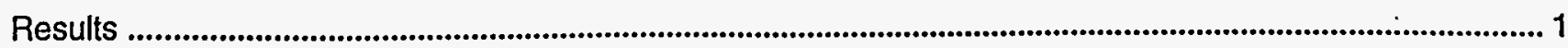

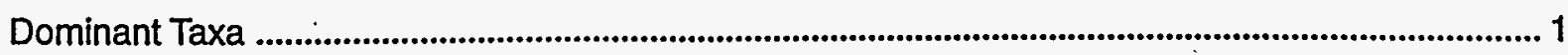

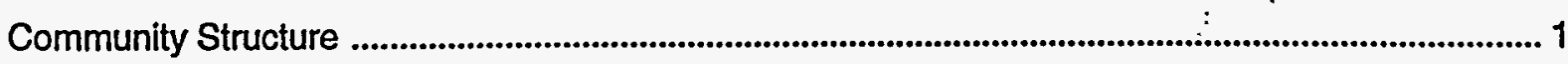

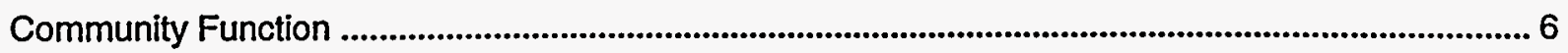

Changes in the Macroinverterbrate Community of L Lake Since 1988 and 1989 ........................................... 6

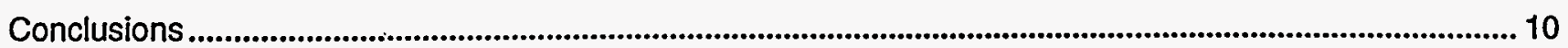

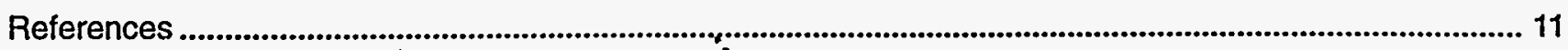

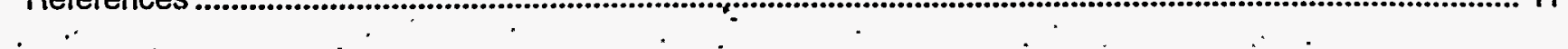




\section{List of Tables}

Table 1.

Benthic macroinvertebrate taxa in L Lake. September 1995

Table 2.

Summary of L-Lake ponar sample data: mean values for Region 5

at 1-, 2-, and 4-meter depths. September 1995

Table 3.

Summary of L-Lake ponar sample data: mean values for Region 7

at 1-, 2-, and 4-meter depths. September 1995

Table 4.

L-Lake ponar sample data from Regions 5 and 7. 1988 and 1989 9

\section{List of Figures}

Figure 1.

Macroinverterbrate sampling locations in L Lake. September 1995 2 


\title{
L-Lake Macrovertebrate Community
}

\author{
Winona L. Specht \\ Westinghouse Savannah River Company \\ Savannah River Technology Center \\ Environmental Sciences Section \\ Aiken, SC 29808
}

\section{Introduction}

To characterize the present benthic macroinvertebrate community of L Lake, Regions 5 and 7 of the reservoir were sampled in September 1995 at the same locations sampled in 1988 and 1989 during the LLake monitoring program. The macroinvertebrate community of 1995 is compared to that of 1988 and 1989.

\section{Methods}

In September 1995, a total of 72 macroinvertebrate grab samples were collected from 4 transects in Region 5 and 4 transects in Region 7 (Figure 1). Along each transect, three replicate samples of substrate were collected at water depths of 1 meter, 2 meters, and 4 meters using a petite ponar dredge measuring 14.5 centimeters by 16.9 centimeters (5.7 inches by 6.6 inches; 0.02451 cubic meters [0.9 cubic feet]). Samples were placed in a tub with a small amount of water, stirred to break apart clumps of sediment, and then sieved through a $0.5-$ millimeter (0.02-inch) mesh sieve bucket. Once sieved, each sample was placed in a labeled 1liter plastic bottle, preserved with $10 \%$ formalin containing rose bengal stain, and returned to the laboratory for processing. In the laboratory, each sample was rinsed through a U.S. Standard No. 30 sieve to remove excess formalin and stain. The macroinvertebrates were sorted from the remaining debris using a stereomicroscope, identified to the lowest practical taxon (usually genus), and enumerated. Quality control checks were performed on $10 \%$ of the samples in order to ensure a sorting efficiency of greater than
90\%. After the organisms were enumerated, they were separated into functional feeding groups following Merritt and Cummins (1984) procedure, dried at $105^{\circ} \mathrm{C}\left(221^{\circ} \mathrm{F}\right)$, weighed to the nearest milligram, and then ashed at $550{ }^{\circ} \mathrm{C}$ $\left(1022^{\circ} \mathrm{F}\right)$. Ash-free dry weight was determined by weighing the remaining ash to the nearest milligram and determining the difference between the dry weight and ash weight.

\section{Results}

\section{Dominant Taxa}

Sixty-seven macroinvertebrate taxa were collected from LLake during the 1995 sampling effort (Table 1). The most dominant taxa in most samples were oligochaetes (32.8-69.7\%) and the amphipod, Hyalella azteca (5.6-30.9\%; Tables 2 and 3). Other taxa that comprised at least $5 \%$ of the organisms in one or more replicates included the chironomid, Cladotanytarsus sp.; the bivalves, Corbicula fluminea and Sphaerium sp.; the caddisflies, Polycentropus sp. and Glyptotendipes paripes; nematode worms; the flatworm, Dugesia tigrina; and the phantom midge, Chaoborus punctipennis. Chaoborus punctipennis and Glyptotendipes sp. were abundant in samples collected at 4 meters, but were collected infrequently at the shallower sampling locations. Conversely, the relative abundance of oligochaetes decreased with increasing depth (Tables 2 and 3).

\section{Community Structure}

The mean number of taxa collected per replicate sample ranged from 12.58 to 16.83 (Tables 2 and 3). Taxa richness in Regions 5 and 7 was similar. 


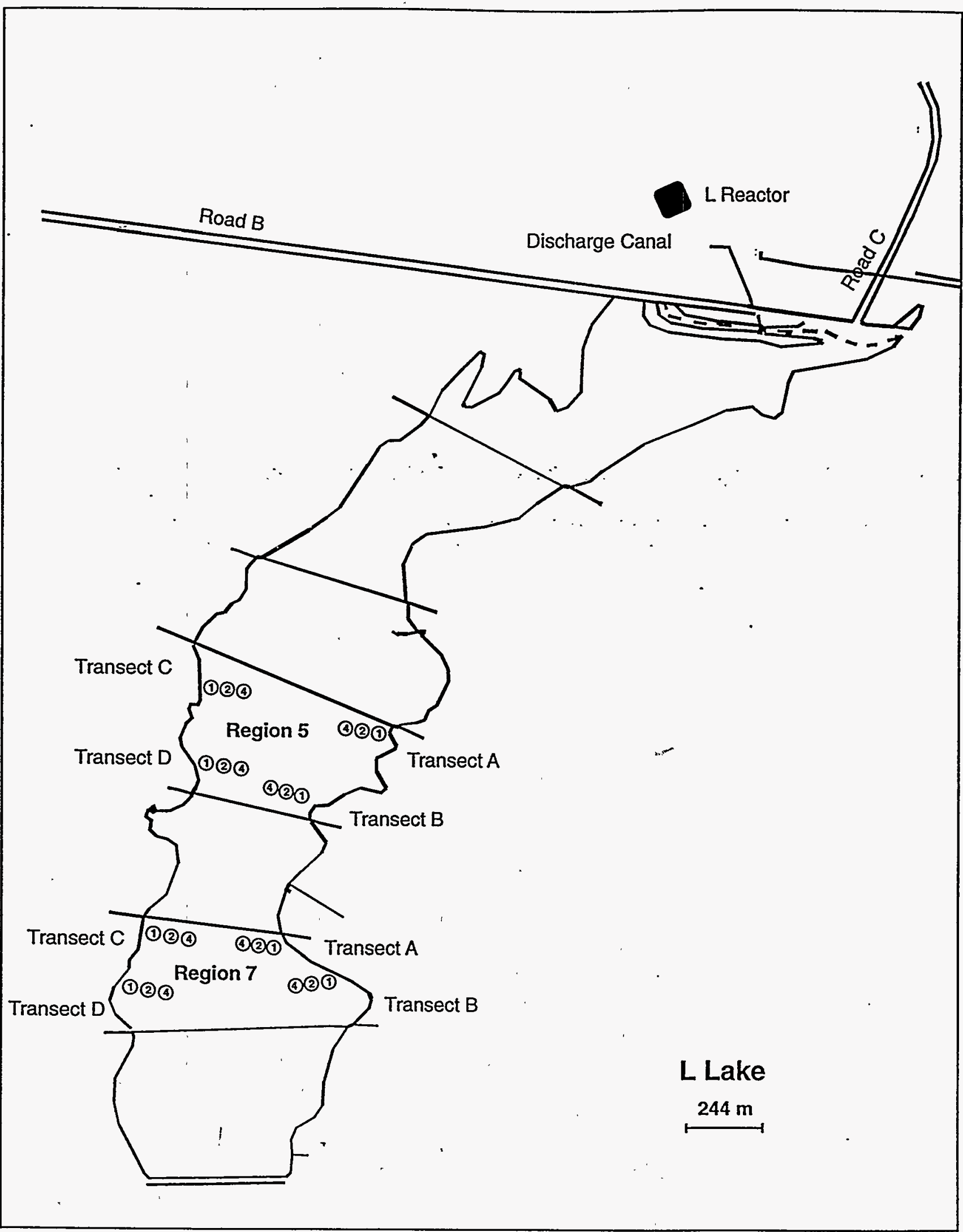

Figure 1. Macroinvertebrate sampling locations in L Lake. September 1995. 
Table 1. Benthic macroinvertebrate taxa in L Lake. September 1995.

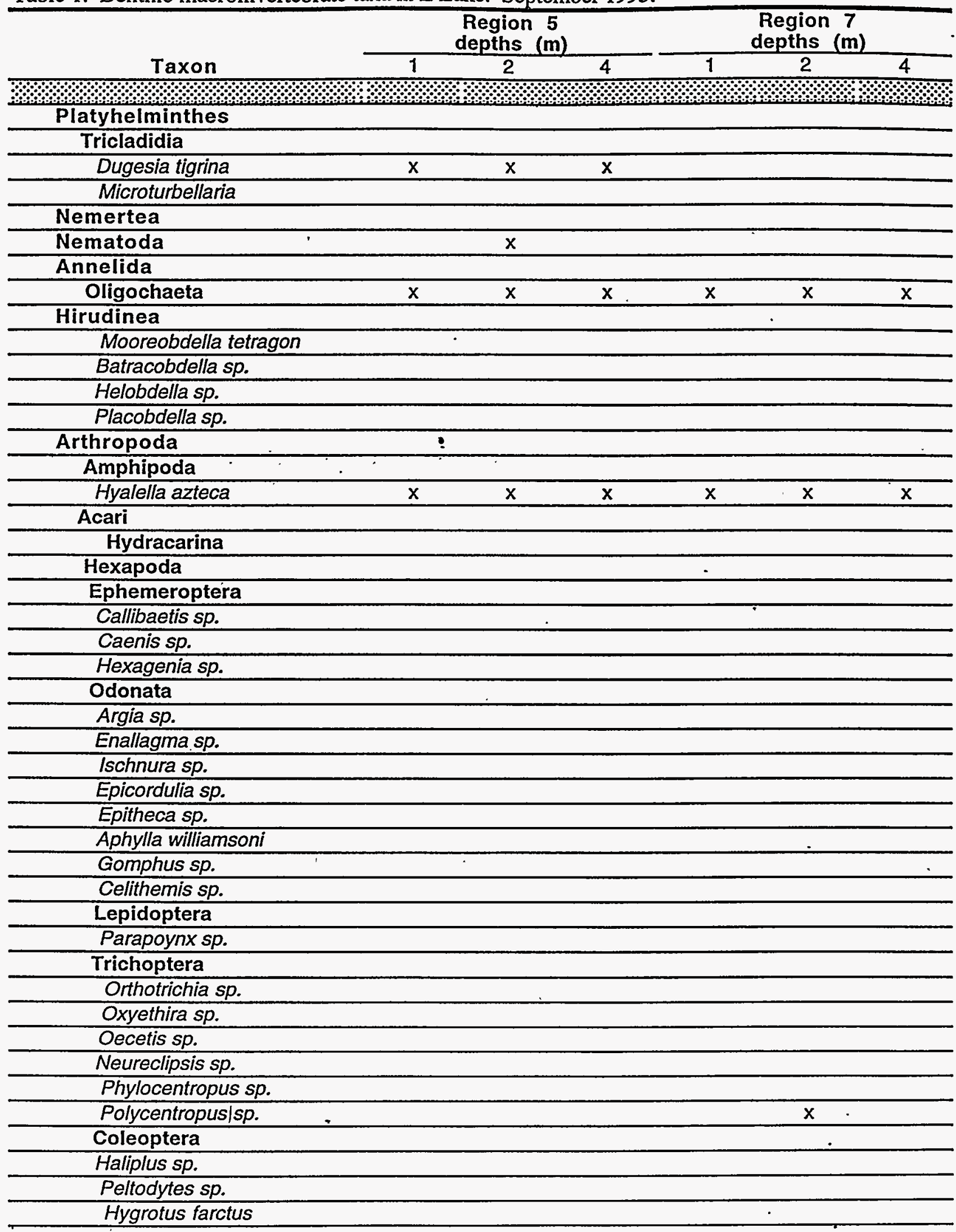

$\mathrm{x}=$ Taxa that comprised at least $5 \%$ of the organisms collected in one or more replicate samples. 
Table 1 (continued) Benthic macroinvertebrate taxa in L Lake. September 1995.

\begin{tabular}{|c|c|c|c|c|c|c|}
\hline \multirow[b]{2}{*}{$\begin{array}{l}\text { Taxon } \\
\end{array}$} & \multicolumn{3}{|c|}{$\begin{array}{c}\text { Region } 5 \\
\text { depths (m) }\end{array}$} & \multicolumn{3}{|c|}{$\begin{array}{c}\text { Region } 7 \\
\text { depths }(m)\end{array}$} \\
\hline & 1 & 2 & 4 & 1 & 2 & 4 \\
\hline \multicolumn{7}{|c|}{ plon } \\
\hline \multicolumn{7}{|c|}{ Diptera } \\
\hline \multicolumn{7}{|l|}{ Ceratopogonidae } \\
\hline \multicolumn{7}{|l|}{ Palpomyia sp. } \\
\hline \multicolumn{7}{|l|}{ Chaboridae } \\
\hline Chaoborus sp. & & & $x$ & & & $\mathbf{x}$ \\
\hline \multicolumn{7}{|l|}{ Chironomidae } \\
\hline \multicolumn{7}{|l|}{ Chironomini } \\
\hline \multicolumn{7}{|l|}{ Chironomus sp. } \\
\hline \multicolumn{7}{|l|}{ Cryptochironomus spp. } \\
\hline \multicolumn{7}{|l|}{ Cryptotendipes sp. } \\
\hline \multicolumn{7}{|l|}{ Dicrotendipes spp. } \\
\hline \multicolumn{7}{|l|}{ Endochironomus sp. } \\
\hline Glyptotendipes paripes & & & $x$ & & & $x$ \\
\hline Glyptotendipes sp. & & & & & & \\
\hline Microchironomus nigrovittatus & & & & & 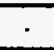 & \\
\hline \multicolumn{7}{|l|}{ Nilothauma babiyi } \\
\hline Parachironomus spp. & s. & & $\cdot$ & & & \\
\hline \multicolumn{7}{|l|}{ Paracladopelma sp. } \\
\hline \multicolumn{7}{|l|}{ Polypedilum spp. } \\
\hline Stictochironomus sp. & & & & & & \\
\hline Orthocladiinae & & & & & & \\
\hline Corynoneura sp. & & & & & & \\
\hline Cricotopus sp. & & & & & & \\
\hline Nanocladius spp. & & & & & & \\
\hline Psectrocladius sp. & & & & & & \\
\hline Thienemanniella sp. & & & & & & \\
\hline Pseudochironomini & & & & & & \\
\hline Pseudochironomus sp. & & & & & & \\
\hline Tanypodinae & & & & & & \\
\hline Ablabesmyia sp. & & & & & & \\
\hline Coelotanypus sp. & & & & & & \\
\hline Djalmabatista pulcher & & & & & & \\
\hline Labrundinia sp. & & & & & & \\
\hline Larsia $s p$. & & & & & & \\
\hline Procladius sp. & & & & & & \\
\hline Tanytarsini & & & & & & \\
\hline Cladotanytarsus spp. & $x$ & $\mathrm{x}$ & $x$ & $\mathrm{x}$ & & $\mathrm{x}$ \\
\hline Tanytarsus spp. & & & & & & \\
\hline Mollusca & & & & & & \\
\hline Bivalvia & & & & & & \\
\hline Corbicula sp. & $x$ & $x$ & $x$ & $x$ & $x$ & $x$ \\
\hline Sphaerium sp. & & & & $x$ & & \\
\hline Gastropoda & & & & & & \\
\hline Ferrissia sp. & & & & & & \\
\hline Physella sp. & & & & & & \\
\hline Planorbidae & & & & & & \\
\hline
\end{tabular}


Table 2. Summary of L-Lake ponar sample data: mean values for Region 5 at 1-, 2-, and 4-meter depths. September 1995.

\begin{tabular}{|c|c|c|c|}
\hline \multirow[b]{2}{*}{ Samples } & \multicolumn{3}{|c|}{ Depth (m) } \\
\hline & 1 & 2 & 4 \\
\hline & & 96 & 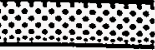 \\
\hline \multicolumn{4}{|l|}{ General descriptions } \\
\hline Taxa richness & 24.50 & 21.75 & 20.50 \\
\hline Mean number $/ \mathrm{m}^{2}$ & 18825.65 & 15524.28 & 8622.33 \\
\hline Number of replicates & 3 & 3 & 3 \\
\hline Mean number taxa/replicate & 16.75 & 13.67 & 13.83 \\
\hline Biomass $\left(\mathrm{g} / \mathrm{m}^{2}\right)$ & 51.63 & 80.52 & 10.79 \\
\hline \multicolumn{4}{|l|}{$\begin{array}{l}\text { Percent relative abundance- } \\
\text { major taxa (number) }\end{array}$} \\
\hline Turbellaria & 4.19 & 5.46 & $\overline{2.83}$ \\
\hline Nemertea & 0.81 & 0.10 & 0.00 \\
\hline Nematoda & 1.38 & 6.94 & 1.13 \\
\hline Annelida-Oligochaeta & 69.70 & 40.27 & 33.67 \\
\hline Annelida-Hirudinea & 0.45 & 0.22 & 0.78 \\
\hline Amphipoda & 5.57 & 30.94 & 22.68 \\
\hline Hydracarina & 0.90 & 0.38 & 0.05 \\
\hline Ephemeroptera & 0.05 & 0.10 & 0.03 \\
\hline Odonata & 0.73 & 0.17 & 0.07 \\
\hline Lepidoptera & 0.03 & 0.00 & 0.00 \\
\hline Trichoptera & 0.82 & 1.23 & 0.48 \\
\hline Coleoptera & 0.00 & 0.00 & .0 .00 \\
\hline Diptera-Ch. Chironomini & 0.80 & 0.81 & 17.57 \\
\hline Diptera-Ch. Orthocladiinae & 0.09 & 0.06 & 0.25 \\
\hline Diptera-Ch. Pseudochironomini & 0.15 & 0.04 & 0.00 \\
\hline Diptera-Ch. Tanypodinae & 1.30 & 0.64 & 1.83 \\
\hline Diptera-Ch. Tanytarsini & 5.56 & 4.69 & 5.32 \\
\hline Diptera-other & 0.34 & 1.54 & 10.04 \\
\hline Mollusca-Bivalvia & 6.37 & 6.13 & 3.21 \\
\hline Mollusca-Gastropoda & 0.74 & 0.26 & 0.05 \\
\hline Total & 100.00 & 100.00 & 100.00 \\
\hline \multicolumn{4}{|l|}{$\begin{array}{l}\text { Percent relative abundance- } \\
\text { functional feeding group (number) }\end{array}$} \\
\hline Collector-filterers & 6.85 & 6.95 & 3.34 \\
\hline Collector-gatherers & 88.63 & 89.03 & 82.32 \\
\hline Herbivores & 0.24 & 0.08 & 0.00 \\
\hline Predators & 3.54 & 3.67 & 14.29 \\
\hline Scrapers & 0.74 & 0.26 & 0.05 \\
\hline Shredders & 0.00 & 0.00 & 0.00 \\
\hline Total & 100.00 & 100.00 & 100.00 \\
\hline \multicolumn{4}{|l|}{$\begin{array}{l}\text { Percent relative abundance- } \\
\text { functional feeding group (biomass) }\end{array}$} \\
\hline Collector-filterers & 87.32 & 97.60 & 90.38 \\
\hline Collector-gatherers & 8.05 & 1.68 & 7.94 \\
\hline Herbivores & 0.01 & 0.00 & 0.00 \\
\hline Predators & 4.15 & 0.63 & 1.45 \\
\hline Scrapers & 0.47 & 0.09 & 0.23 \\
\hline Shredders & 0.00 & 0.00 & 0.00 \\
\hline Total & 100.00 & 100.00 & 100.00 \\
\hline
\end{tabular}


Table 2 (continued): Summary of L-Lake ponar sample data: mean values for Region 5 at 1-, 2-,

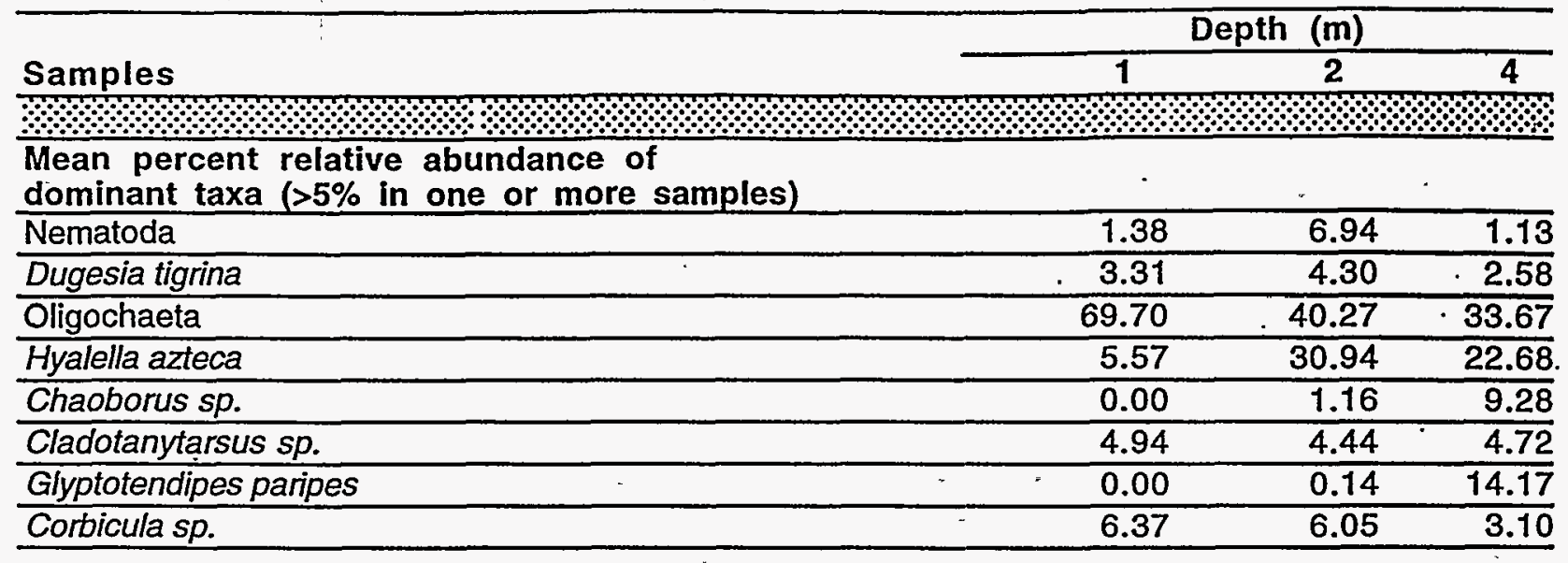

In general, fewer taxa were collected as water depth increased. Densities of organisms were somewhat higher in Region 5 (8622 to 18,826 organisms per square meter $\left.\left[\mathrm{m}^{2}\right]\right)$ than in Region 7 ( 7184 to 11,628 organisms $/ \mathrm{m}^{2}$ ). In both regions, densities decreased with increasing depth. Macroinvertebrate standing crop (biomass) was also considerably higher in Region 5 at the 1-meter and 2-meter depths $\left(51.6\right.$ grams $[\mathrm{g}] / \mathrm{m}^{2}$ and $80.5 \mathrm{~g} /$ $\mathrm{m}^{2}$, respectively) than in Region 7 (12.2 and 27.4 $\mathrm{g} / \mathrm{m}^{2}$, respectively), but the biomass of samples collected at a depth of 4 meters in Region 7 (16.6 g/ $\mathrm{m}^{2}$ ) was somewhat higher than that at 4 meters in Region $5\left(10.8 \mathrm{~g} / \mathrm{m}^{2}\right)$.

\section{Community Function}

Collector-gatherers were by far the most abundant functional feeding group collected in Regions 5 and 7 of L Lake, comprising 73.4-89.4\% of the organisms collected (Tables 2 and 3). Most of the collector-gatherers were worms, amphipods, or chironomids.

Collector-filterers accounted for 3.3-7.5\% of the organisms collected from the ponar grab samples and were almost all bivalves. Predators accounted for $14.3 \%$ and $20.8 \%$ of the organisms collected from 4-meter depths, but less than $4 \%$ of the organisms collected from 1-and 2-meter depths. The phantom midge, Chaoborus punctipennis, which is a predator that resides in the deep-water sediments and rises at night to feed in the water column, was the dominant predator in the 4-meter samples. The remaining functional feeding groups (herbivores, scrapers, and shredders) each accounted for less than $2 \%$ of the organisms collected.

With respect to functional group biomass, collector-filterers were dominant, accounting for $66.2-$ $97.6 \%$ of the biomass at a sampling location. The relatively large size of filter-feeding bivalves accounted for the large filterers-feeder biomass. In Region 7, collector-gatherer biomass was higher (13.2-22.7\%) than in Region 5 (1.7-8.0\%). The remaining functional feeding groups each accounted for less than 5\% of the total biomass at a sampling location.

\section{Changes in the Macroinvertebrate Community of L Lake Since 1988 and 1989}

The taxonomic composition of the L-Lake macroinvertebrate community has changed considerably since the macroinvertebrate community was last sampled in the late 1980s. The relative abundance of Chironomini midges has declined substantially, while amphipods, oligochaetes, Tanytarsini midges, Turbellaria, bivalves (primarily Corbicula fluminea), and the phantom midge, Chaoborus punctipennis, have increased in abun- 
Table 3. Summary of L-Lake ponar sample data: mean values for Region 7 at 1-, 2-, and 4-meter depths. September 1995.

Samples

$\frac{\text { Depth (m) }}{2}$

General descriptions

Taxa richness

\section{.}

Mean number/m²

Number of replicates

Mean number taxa/replicate

Biomass $\left(\mathrm{g} / \mathrm{m}^{2}\right)$

Percent relative abundance-major taxa (number)

Turbellaria

Nemertea

Nematoda

Annelida-Oligochaeta

Annelida-Hirudinea

Amphipoda

Hydracarina

Ephemeroptera

Odonata

Lepidoptera

Trichoptera

Coleoptera

Diptera-Ch. Chironomini

Diptera-Ch. Orthocladiinae

Diptera-Ch. Pseudochironomini

Diptera-Ch. Tanypodinae

Diptera-Ch. Tanytarsini

Diptera-other

Mollusca-Bivalvia

Mollusca-Gastropoda

Total



27.25

627.91

16.83

12.18

22.25

\begin{tabular}{rr}
7510.54 & 7184.14 \\
\hline 3 & 3
\end{tabular}

3.

1.79

0.27

1.97

56.70

0.30

20.55

0.06

0.07

1.57

0.00

1.17

0.10

1.23

0.80

2.11

2.71

2.33

0.58

4.18

1.52

Percent relative abundance-

functional feeding group (number)

Collector-filterers

Collector-gatherers

100.00

Herbivores

Predators

Scrapers

Shredders

Total

\begin{tabular}{rrrr}
\hline 5.17 & 7.46 & 5.22 \\
\hline 89.40 & 87.35 & 73.42 \\
\hline 0.20 & 0.58 & 0.04 \\
\hline 3.72 & 2.98 & 20.81 \\
\hline 1.52 & 1.63 & 0.51 \\
\hline 0.00 & 0.00 & 0.00 \\
\hline 100.00 & 100.00 & 100.00 \\
\hline & & & \\
\hline 66.18 & 68.10 & 83.19 \\
\hline 22.67 & 20.71 & 13.23 \\
\hline 0.05 & 0.69 & 0.02 \\
\hline 8.24 & 3.09 & 2.83 \\
\hline 2.86 & 7.40 & 0.74 \\
\hline 0.00 & 0.00 & 0.00 \\
\hline 100.00 & 100.00 & 100.00 \\
\hline
\end{tabular}


Table 3 (continued). Summary of L-Lake ponar sample data: mean values for Region 7 at 1-, 2-, and 4-meter depths. September 1995.

\begin{tabular}{|c|c|c|c|}
\hline \multirow[b]{2}{*}{ Samples } & \multicolumn{3}{|c|}{ Depth (m) } \\
\hline & 7 & 2 & 4 \\
\hline an & $\because$ & 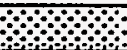 & 6 \\
\hline $\begin{array}{l}\text { Mean percent relative abundance of } \\
\text { dominant taxa ( }>5 \% \text { in one or more samples) }\end{array}$ & & & $:$ \\
\hline Nematoda & 1.97 & 5.71 & 4.41 \\
\hline Dugesia tigrina & 1.68 & 0.69 & 2.60 \\
\hline Oligochaeta & 56.70 & 44.69 & 32.77 \\
\hline Hyalella azteca & 20.55 & 28.99 & 23.82 \\
\hline Polycentropus sp. & 1.00 & 1.56 & 0.44 \\
\hline Chaoborus sp. & 0.06 & 0.05 & 17.76 \\
\hline Cladotanytarsus sp. & 3.02 & 2.55 & 4.03 \\
\hline Glyptotendipes paripes & 0.43 & 1.02 & 3.57 \\
\hline Corbicula sp. & 2.72 & 4.85 & 3.76 \\
\hline Sphaerium sp. & 1.46 & 0.97 & 1.02 \\
\hline
\end{tabular}

dance. Amphipods exhibited the greatest increase in relative abundance. In 1988 and 1989, amphipods accounted for less than $1 \%$ of the macroinvertebrates collected at all locations except Region 7, 2-meter depth, where they were locally abundant and comprised $18.57 \%$ of the organisms collected (unpublished data). However, in 1995, amphipods were abundant at all sampling locations, comprising $5.57-30.94 \%$ of the benthic fauna.

The shift in the structure of the macroinvertebrate community is due, at least in part, to the development of beds of aquatic macrophytes in L Lake as the reservoir matured. L Lake was filled in October 1985. In 1988 and 1989, L Lake supported a still relatively immature ecosystem that was undergoing rapid succession. By 1995, the reservoir was 10 years old and had sufficient time to develop a more mature ecosystem with some early successional species replaced by other species as the ecosystem became more stable.

In 1988 and 1989, macroinvertebrate densities were highest in the samples collected from the 2-meter depth of Region 5 (22,593 organisms $/ \mathrm{m}^{2}$ in 1988 and 22,907 organisms $/ \mathrm{m}^{2}$ in 1989 ; Table 4). Densities at 2 meters in Region 7 were substantially lower, averaging 13,873 organisms $/ \mathrm{m}^{2}$ in 1988 and
11,270 organisms $/ \mathrm{m}^{2}$ in 1989: In contrast, in the samples collected at a depth of 4 meters, densities were somewhat higher in Region 7 ( 7378 and 8598 organisms $/ \mathrm{m}^{2}$ in 1988 and 1989 , respectively) than in Region 5 (5346 and 4244 organisms $/ \mathrm{m}^{2}$ in 1988 and 1989, respectively).. In both regions and in both years, macroinvertebrate densities were substantially higher at a depth of 2 meters than at 4 meters.

Macroinvertebrate densities in 1995 , collected from a depth of 2 meters in both Region $5(15,524$ organisms $\left./ \mathrm{m}^{2}\right)$ and Region $7\left(7510\right.$ organism $\left./ \mathrm{m}^{2}\right)$, were substantially lower than densities at the same locations in 1988 and 1989. However, densities at the 4-meter depth were fairly similar among years. In new reservoirs, secondary production is often high during the first several years, but tends to decline as the reservoir ecosystems mature (Paterson and Fernando 1970; Voshell and Simmons 1984). Thus, the higher densities observed at 2meter depths during the early years of $L$ Lake's development probably are related to the early successional stage of the reservoir.

\section{Conclusions}

The species composition of. L Lake's macroinvertebrate community has changed con- 
Table 4. L-Lake ponar sample data from Regions 5 and 7. 1988 and 1989.

\begin{tabular}{|c|c|c|c|c|c|c|c|c|}
\hline Year & 1988 & 1988 & 1988 & 1988 & 1989 & 1989 & 1989 & 1989 \\
\hline \multirow{2}{*}{\multicolumn{9}{|c|}{$\begin{array}{l}\text { Percent relative abundance } \\
\text { Perce }\end{array}$}} \\
\hline & & & & & & & & \\
\hline Turbellaria & 0.13 & 0.00 & 0.00 & 0.00 & 0.00 & 0.00 & 0.00 & 0.00 \\
\hline Nematoda & 1.55 & 9.16 & 1.14 & 1.81 & 1.76 & 0.76 & 0.58 & 0.00 \\
\hline Annelida-Oligochaeta & 14.62 & 18.56 & 12.22 & 15.94 & 7.79 & 41.51 & 41.19 & 33.11 \\
\hline Annelida- Hirudinea & 0.05 & 0.00 & 0.00 & 0.00 & 0.04 & 0.00 & 0.00 & 0.00 \\
\hline Ephemeroptera & 0.00 & 0.16 & 0.59 & 0.00 & 0.70 & 0.00 & 0.15 & 0.00 \\
\hline Odonata & 0.00 & 0.00 & 0.00 & 0.00 & 0.23 & 0.00 & 0.54 & 0.00 \\
\hline Trichoptera & 0.05 & 0.00 & 0.20 & 0.00 & 0.24 & 0.00 & 0.30 & 0.00 \\
\hline Coleoptera & 0.00 & 0.00 & 0.00 & 0.00 & 0.04 & 0.00 & 0.00 & 0.00 \\
\hline Homoptera & 0.00 & 0.00 & 0.00 & 0.00 & 0.04 & 0.00 & 0.05 & 0.00 \\
\hline Diptera-Ch. Chironomini & 81.46 & 65.72 & 81.41 & 71.50 & 82.58 & 31.64 & 22.13 & 43.15 \\
\hline Diptera- Ceratopogonidae & 0.42 & 0.31 & 0.76 & 0.00 & 0.47 & 1.21 & 0.48 & 0.60 \\
\hline Diptera- Chaoborus & 0.00 & 0.75 & 0.00 & 5.28 & 0.00 & .10 .21 & 1.01 & 20.11 \\
\hline Diptera-Other & 0.21 & 0.45 & 1.87 & 0.52 & 2.49 & 0.56 & 1.06 & 0.52 \\
\hline Mollusca-Bivalvia & 1.23 & 0.00 & 0.28 & 0.00 & 0.80 & 4.59 & 2.41 & 0.97 \\
\hline Mollusca-Gastropoda & 0.00 & 0.00 & 0.04 & 0.00 & 0.07 & 0.00 & 0.00 & 0.00 \\
\hline Density (number $/ \mathrm{m}^{2}$ ) & $22,593.40$ & $5,345.70$ & $13,872.90$ & $7,378.40$ & $22,906.90$ & $4,243.80$ & $11,270.20$ & $8,598.50$ \\
\hline
\end{tabular}


siderably since $1988-1989$, due primarily to maturation of the reservoir ecosystem. L Lake contains a reasonably diverse macroinvertebrate community that is capable of supporting higher trophic levels, including a diverse assemblage of fish species. The L-Lake macroinvertebrate community is similar to those of many other southeastern reservoirs, and there is no indication that the macroinvertebrate community is perturbed by chemical or physical stressors. 


\section{References}

Merritt, R. W., and K. W. Cummins. 1984. An Introduction to the Aquatic Insects of North America. 2nd. ed. Kendall/Hunt Publ. Co. Dubuque, IA.

Paterson, C. G., and C. H. Fernando. 1970. Benthic fauna colonization of a new reservoir with particular reference to the Chironomidae. Journal of the Fisheries Research Board of Canada 27:213-232.

Voshell, J. R. Jr., and G. M. Simmons. 1984. Colonization and succession of benthic macroinvertebrates in a new reservoir. Hydrobiologia 112:27-39. 